\title{
The Influence of Introductory Accounting Course Content on Students Choice of Accounting Major in Kenyan Universities
}

\author{
Dr. Grace Akinyi Musa, \\ School of Business and Management Studies, Department of Accounting and Finance, Technical University of \\ Kenya
}

\begin{abstract}
The purpose of the study was to examine the influence of Introductory Accounting Course content on students' choice of Accounting Major in Kenyan Universities. Introductory Accounting Course content has been under attack by students in most Universities across the world. The course has been viewed as: difficult to pass, number oriented, not exposing students to practice, comprising of rules and regulations encouraging rot learning and therefore dull and boring. The negative perceptions by students towards the course have led to low uptake of Accounting Major. These facts notwithstanding, research shows that Introductory Accounting Course Content is the foundation on which accounting career is grounded. Students' should be introduced well to the basics of the course, including the accounting cycle and accounting principles. Mastery of these concepts at the earliest opportunity possible not only heightens the comprehension of the course, but also perfects its application in the business world. This would bridge the mismatch that existed between skills posed by the fresh accounting graduates on entry into the job market and employers requirements and expectations. A descriptive cross sectional Research design was adopted. The study sampled students undertaking Bachelor of Commerce degree in twelve selected Kenyan universities and employed a mixture of purposive and stratified random sampling technique to select the Sample of students from the target population. The study adopted a logistic regression model. The research findings revealed that Introductory Accounting Course had a positive significant influence on students' choice of Accounting Major in Kenyan Universities. The results can be used to make the course more attractive to students' which would lead to increase in the uptake of Accounting Major in the universities. The study focused on Introductory Accounting Course content as opposed to other studies that previously focused on other aspects of Accounting Major such as earnings, job market conditions and career opportunities as influencers of career choices in accounting among students in universities. The study's greatest contribution to the knowledge of accounting has been witnessed in its attempt to address the survival of accounting profession. This include: giving more attention to Introductory Accounting Course content by availing relevant teaching materials, application of appropriate delivery methods and employability of competent Introductory Accounting Course Instructors.
\end{abstract}

Keywords: Introductory Accounting Course Content, Kenyan Universities, Students choice, Accounting Major

DOI: $10.7176 / \mathrm{JEP} / 11-9-23$

Publication date:March $31^{\text {st }} 2020$

\subsection{Introduction}

Introductory Accounting Course (IAC) is compulsory to all students in the Schools of Business in most Universities across the world. The course acts as an eye opener and screening tool into accounting major (Kenyan Universities B.Com syllabi, 2018). Most students in the schools of business in most Universities across the world end up not choosing accounting specialization despite undertaking IAC. The low uptake of Accounting Major pointed out to a serious problem with the content of IAC which needed urgent attention. It is important to note that the Course content of Introductory Accounting Course is grounded on the ten steps of Accounting cycle including: Identification and Analysis of documents; Journalizing Entries; Posting Journal to Ledger; Balancing off of the ledger Accounts; Preparing Unadjusted Trial Balance; Preparing a work sheet; Recording adjusting entries; preparing Financial statements; making Closing entries to ascertain that the accounts balance. The final trial balance is prepared as the provisional ones have been closed only the lasting accounts appear on the closing trial balance to make sure that debits equal credits (Frank \& Sangster, 2015; Gupta \& Radhaswamy, 2014).

From the steps of the Accounting Cycle above, a chronological sequence was to be observed such that knowledge learnt from the previous step was carried forward to the next step and this was applicable to all other steps 
(Swanson, 2010). This implied that when a student missed out on one step then the rest of the steps would not be comprehended. The end result would be that students were likely to find the course and entire accounting difficult which would impart negatively on their choice of Accounting Major. To fully understand Accounting Cycle, it was important that students had a solid understanding of the basic accounting principles. The knowledge of these principles would enable them prepare accurate financial statements.

Recognition entity concept is where an element of financial statement will not be recognised unless a reliable value can be assigned to it (Frank \& Sangster, 2015). Matching Principle is whereby monthly costs associated with revenues are recorded without carrying over the expenses as these would overstate the net profit figure for that month (Gupta \& Radhaswamy, ,2014). Accrual Principle of Accounting requires that all income and charges relating to the financial period to which the financial statements relate should be taken into account without regard to the date of receipt or payment. Failure to include the accrued expenses and revenues in the income statement will overstate and understate expenses and revenues respectively. Accrual concept thus plays a significant role in the preparation of financial statement which is the sixth step in the Accounting Cycle and Introductory Accounting Course as a whole. Historical cost principle records assets at net books as each asset is acquired. Assets can be equipment or real property. All noncurrent assets are recorded using their original cost minus total depreciation in the statement of financial position (Wood \& Sangster, 2015). It is clear that in order to come up with accurate financial statements; students must apply accounting principles correctly.

Research has shown that due to the chronological sequence of IAC content, most students developed negative perceptions towards the course. In New Zealand Universities, most students perceived the course to be dull and boring they further reported that IAC content was pegged on procedural rules of Generally Accepted Accounting Principles and double entry system (Malthius \& Fowler, 2009). Prior studies concentrated on criticizing the contents of IAC and did not evaluate the course content directly on the choice of Accounting Major.

\subsection{Theoretical Review \\ 2.1.1 Wearing Two Hats Theory (1996)}

This theory was developed by Berg (1996) It explained that IAC topics be given dual treatment as per the double entry concept states, that is, accounting entries are opposite when approached at the viewpoint of different people. The theory focuses on teaching IAC topics. He stressed that when teaching accounting topics such as Bank Reconciliation where the cash book must be adjusted first, accounting Instructor should wear two hats, one for the customers, Cash Book and the other one for the Bank Statement(Jayaprakash, 2005). Wearing Two Hats theory is important to the current study as it focuses on broadening students' critical thinking in accounting which is much needed in process of accounting cycle which is the backbone of the current study

\subsubsection{Theory of Planned Behaviour}

This theory focuses on Perceived behavioural control which means that people are driven by their perceptions of the ease or difficulty of performing the behaviour of interest. Ajzen (1991) added the theory of Planned Behaviour in an attempt to understand the boundaries of an individual in order to perform certain behaviours. According to the theory, if the attitude, subjective norms with respect to a behaviour and perceived behavioural control are favourable, an individual intention to perform the behaviour is stronger and vis-à-vis.

This theory is important to the current study in that before a student decides on whether to choose Accounting Major after undertaking IAC, satisfaction must be derived based on the course content. The theory has been used by a number of researchers in the accounting field including; Tan and Laswad (2006) used the theory of planned behaviour to study factors that affect students ${ }^{\text {ee }}$ intentions to major in accounting and non-accounting disciplines. A survey of a sample of business students enrolled on an Introductory Accounting Course in a New Zealand university was conducted to gather data about their intended academic majors, and their beliefs and attitudes towards majoring in accounting and non-accounting. The results showed that three factors - personal, referents, and control - were determinants of students ${ }^{e e}$ intention to major in accounting. Referents included, Parents, relatives Instructors of IAC.

\subsection{Empirical Review}

Prior studies on Introductory Accounting Course content reported numerous results on students' perceptions. Studies conducted at the United Kingdom universities by (Marriott \& Marriott, 2003) established that there was a 
problem with Introductory Accounting content and teaching at the Universities which sent negative signals to most students concerning the course.

Introductory Accounting Course was compulsory to all students in most Universities across the world (Sang \& Tang (2016). Research carried out in most USA Universities showed that most students took Introductory Accounting Course as a gate way to obtaining undergraduate degree certificates. However, they did not enjoy the course content which they criticised as number oriented, full of rules and regulations which didn't make much sense to them (Principe, 2005; Omar, 2009).

A study by Shattock (2005) established that there was a problem with the delivery of accounting content by the accounting Instructors which made accounting difficult to pass even after a re-sit of the course at the University. This made most students conclude that accounting was a difficult subject to pass.

A study by Swanson (2010), divided accounting students in an IAC class into two groups; those who understood the accounting cycle and those who didn't. Findings of the study revealed that those students who mastered the ten steps of accounting cycle performed well in IAC. This was contrary to their counterparts who had no mastery of accounting cycle.

Reports from the World Bank and International Monetary Fund (2017) carried out a research on the qualities of graduates employed by most organizations across the world. Findings established that most Organizations across the world had ended up employing unqualified graduates in most fields including accounting to take up the respective jobs.

A study conducted by Ovalle (2006) claimed that accounting content overloaded students with static skills and knowledge and as a result students and accountants were blinded to the failings and deficiencies that were intrinsic within the profession. A similar view was held by (Athiyaman, 2001), findings showed that students were of the opinion that universities were not developing them fully as required by their future employers. This finding was supported by a study carried out by (Kavangah \& Drennan, 2008) which established that there was a mismatch between skills posed by accounting graduates on entry into the job market and employers expectations.

Studies conducted by Royce, Mark and Ya-wen (2008), on The Change of Student's Perception of Accounting Skills in Intermediate Accounting. It assessed accounting and non-accounting majors' perceptions of their accounting knowledge of material covered in the introductory Accounting Course which included journalizing transactions, financial statement preparation, financial statement interpretation and financial statement analysis. Results showed that both accounting and non-accounting majors had different learning outcomes (measured by perception of abilities) under the same learning environment.

Numerous studies conducted on Introductory Accounting Course did not present a universal agreement. The studies focused mainly on the shortcomings of Introductory Accounting Course. Further, most of the studies were carried out in developed countries. The influence of Introductory Accounting Course on students' choice of Accounting Major was lacking, thus creating a necessity of the current study.

\subsection{Conceptual Framework}

A conceptual framework can be defined as a set of broad ideas and principles taken from relevant fields of enquiry and used to structure a subsequent presentation Reichel and Ramey (1987). A conceptual framework is a model which shows the major variables examined in the study and the interrelationships that exists between the variables. It is the act of creating or formulating something by linking up particular ideas or actions intended to deal with the problem or situation (Cooper and Schindler, 2011).

In the current study, the conceptual framework had one independent variable - Introductory Accounting Course content and one dependent variable students' choice of Accounting Major in Kenyan Universities. 


\section{(Independent Variable)}

\begin{tabular}{|l|l|l|}
\hline $\begin{array}{c}\text { INTRODUCTORY ACCOUNTING } \\
\text { COURSE CONTENT } \\
\text { Accounting Principles }\end{array}$ & $\mathrm{H}_{01}$ & $\begin{array}{c}\text { CHOICE OF ACCOUNTING } \\
\text { MAJOR } \\
\text { Accounting cycle }\end{array}$ \\
\cline { 2 - 3 } & & $\begin{array}{l}\text { Accounting Major } \\
\text { Non-Accounting Major }\end{array}$ \\
\hline
\end{tabular}

(Dependent Variable)

Figure 2.0 Conceptual Framework

\section{Source: Author (2020)}

\subsection{Data and Research Methodology}

The study adopted a positivistic philosophical approach. A Descriptive cross sectional Research design was employed. The study sampled students undertaking Bachelor of Commerce degree in twelve selected Kenyan universities. The researcher applied for a research permit from National Commission for Science Technology and Innovation (NACOSTI) to facilitate data collection in the selected Kenyan Universities. The study adopted a mixture of purposive and stratified random sampling technique to select the sample of students from the target population. To draw conclusions on the objectives which are to determine the influence of the independent variable on the dependent variables, a statistical model was fitted to determine the influence of Introductory Accounting Course on students' choice of Accounting as a major

\subsection{Results and Discussions}

\subsection{Data Findings}

The findings suggest that performance in Introductory Accounting Course has an influence on students' choice of Accounting as a Major in Kenyan Universities. The dependent variable was the choice of accounting as a major by the students who had specialised after taking an Introductory Accounting Course. The variable was measured as a dichotomous categorical variable with only two possible outcomes. As shown in table 4.9 only $28 \%$ of the respondents had chosen accounting option as a major while $72 \%$ of the respondents continued with other courses after having taken introductory to accounting. This shows how very few of those who take the introductory to accounting end up dropping accounting to take up other options.

Table 4.1: Choice of Accounting

\begin{tabular}{lll}
\hline & Frequency & Percentage \\
\hline Chose accounting & 89 & 28 \\
Did not choose accounting & 226 & 72 \\
Total & 315 & 100 \\
\hline
\end{tabular}

\subsection{Course Content}

The variable course content was measured using four indicators from the questionnaire of Responses as indicated in Table 4.2 
Table 4.2: Course Content Indicators

\begin{tabular}{|c|c|c|c|c|c|}
\hline & $\begin{array}{l}\text { Not at } \\
\text { all }\end{array}$ & Small & Some & Greater & $\begin{array}{l}\text { Extraordi- } \\
\text { nary }\end{array}$ \\
\hline Dominated by double-entry concept & & & & & \\
\hline & 17 & 30 & 82 & 121 & 65 \\
\hline $\begin{array}{l}\text { Enabled amicable preparation of } \\
\text { financial statement }\end{array}$ & 12 & 22 & 72 & 119 & 90 \\
\hline $\begin{array}{l}\text { Too number oriented, heavily relied } \\
\text { on textbook hence boring }\end{array}$ & 78 & 83 & 82 & 51 & 21 \\
\hline hence difficult & 100 & 63 & 68 & 59 & 25 \\
\hline
\end{tabular}

To measure this variable, the respondents were asked extent to which the course content was dominated by double entry concept which made the course interesting. There were $5.4 \%$ of the respondents who didn't find this to any extent at all, $9.5 \%$ of the students thought it was to a small extent while $26 \%$ of the students only to some extent. There were $38.4 \%$ students who found double entry concept dominating the course to a greater extent while to $20.6 \%$ of the respondents; it was to an extraordinary extent. In this indicator, most respondents indicated that, on average, double entry concept dominated to a greater extent which made the course interesting for the students in the universities in Kenya.

On whether the introductory to accounting course content enabled them to prepare financial statements amicably, $3.8 \%$ of the respondents, responded that course content did not enable them at all, $7 \%$ of the students were enabled to a small extent while to $22.9 \%$ of them some extent. To $37.8 \%$ students, the course content was enabling to a greater extent and $28.6 \%$ of the respondents believed the course content extraordinarily enabled them to prepare financial statements amicably. Most responses on this indicator implied that, on average, the course content enabled the students in the universities in Kenya to prepare financial statements amicably to a greater extent.

The respondents also responded the question on whether the course content for introductory to accounting was too number oriented, heavily relied on the contents of text books and boring. This was perceived not to be true at all by $24.8 \%$ of the respondents, true to a small extent by $26.3 \%$ of the students and true to some extent by $26 \%$ of them. To $16.2 \%$ of the students, the course content for introductory to accounting was to a greater extent too number oriented, heavily relied on the contents of text books and boring and to $6.7 \%$ of the respondents it was extraordinarily true. Most responses on this indicator implied that, on average, the students in the universities in Kenya only to a small extent find the course content for introductory to accounting to be too number oriented, heavily relied on the contents of text books and boring.

Considering the indicator on the level of agreement with the statement that introductory to accounting was dominated by lots of procedural rules and the students found it difficult to cope with the Course, $31.7 \%$ of the respondents found this not true at all. To $20 \%$ of the students, this made them find the course to a small extent dominated by lots of procedural rules while to $21.6 \%$ of them found it so to some extent. Another $18.7 \%$ of the students stated that the course was to greater extent dominated by lots of procedural rules and to $7.9 \%$ of the respondents it was dominated to an extraordinary extent that made it difficult to cope with the course. Responses on this indicator implied that on average, course content was not dominated at all by lots of procedural rules to make it difficult to cope with the Course.

\subsection{Cross-Tabulations between Indicators of Course Content and Choice of Accounting}

Summary of cross-tabulations between each of the four indicators of course content and the choice of accounting option is given in Table 4.8. Similarly, we denoted those majoring in accounting as the "Yes" category while the other category not majoring in accounting denoted as "No" category. Also, the corresponding Pearson's Chi-square values and p-values were as given in Table 4.3 
Table 4.3: Cross-Tabulations between Indicators of Course Content and Choice of Accounting

\begin{tabular}{|c|c|c|c|c|c|c|c|c|c|}
\hline & & Sc & & & & & & Pearson's & \\
\hline $\begin{array}{l}\text { Indicators of Course } \\
\text { Content }\end{array}$ & Choice & 1 & 2 & 3 & 4 & 5 & Total & $\chi^{2}(4$ d.f $)$ & Sig. \\
\hline Dominated by double- & Yes & 4 & 3 & 18 & 44 & 20 & 89 & 10.854 & 0.028 \\
\hline entry concept & No & 13 & 27 & 64 & 77 & 45 & 226 & & \\
\hline Enabled amicable & Yes & 2 & 4 & 16 & 38 & 29 & 89 & 4.682 & 0.322 \\
\hline $\begin{array}{l}\text { preparation of financial } \\
\text { statement }\end{array}$ & No & 10 & 18 & 56 & 81 & 61 & 226 & & \\
\hline Too number oriented, & Yes & 28 & 28 & 22 & 9 & 2 & 89 & 10.025 & 0.040 \\
\hline $\begin{array}{l}\text { heavily relied on textbook } \\
\text { hence boring }\end{array}$ & No & 50 & 55 & 60 & 42 & 19 & 226 & & \\
\hline Dominated by procedural & Yes & 37 & 21 & 15 & 10 & 6 & 89 & 9.608 & 0.044 \\
\hline rules hence difficult & No & 63 & 42 & 53 & 49 & 19 & 226 & & \\
\hline
\end{tabular}

Considering the indicator on whether the course content of introductory to accounting was dominated by double entry concept which made the course interesting, the cross tabulation with the choice of accounting showed that more of the respondents who chose accounting major responded with high scores for this indicator with the majority 44 students responding with a score of 4 to imply 'Small.' For students who did not major in accounting, more students cumulatively responded with higher scores, with the score of 4 having majority of 77 responses.

Based on the chi-square statistic of 10.854 and a p-value of 0.028 , which was less than 0.05 , we rejected the null hypothesis developed in Section 2.5 on this indicator. We thus, made a conclusion that at $95 \%$ confidence level, the data showed a significant association between this indicator and choice of accounting major. This finding is consistent with a study which established that IAC is dominated by accounting principles and rules which are theoretical; lecture method makes the course interesting

(Gill, 2005). This finding implied that inclusion of double entry concept in IAC made the course interesting to students and consequently, influenced their choice of Accounting as a Major.

On whether the course content enabled students to prepare financial statements amicably, it was generally observed that both students majoring and not majoring in accounting indicated higher scores on this indicator. Based on the corresponding chi-square test which gave a chi-square statistic of 4.682 and a p-value of 0.322 which is more than 0.05 , we failed to reject the corresponding null hypothesis developed on this indicator at $95 \%$ confidence level. This decision implied that the data did not provide significant association between this indicator and choice of accounting major at $95 \%$ confidence level. Despite this inference, prior studies have reported contradicting results on this variable. IAC enables students grasp the fundamental knowledge of the accounting concepts such as double entry concept of book keeping, the application of Generally Acceptable Accounting Principles and the preparation of financial statements of different entities amicably (McDowall \& Jackling, 2010). The finding implied that there was a significant association between ability to prepare financial statements amicably and students' choice of Accounting as a Major.

For the question of whether the course content was too number oriented, heavily relied on the contents of text books and boring, the study observed that more of those chose accounting major responded with higher scores for this indicator with the majority 28 students responding with a score of 1 to imply 'Extraordinary.' The respondents who choose not to continue with accounting major, it was observed that more students responded with the score of higher scores for this indicator with the score of 3 having majority of 60 responses. The general conclusion from the contingency table was drawn from a chi-square test which gave a chi-square statistic of 10.025 and a p-value of 0.04 which is less than 0.05 . This implied that the data shows a significant association between this indicator and choice of accounting major at $95 \%$ confidence.

From the indicator on whether the course content of introductory to accounting course was dominated by lots of procedural rules and I found it difficult to cope with the Course, the cross tabulation with the choice of accounting major showed that more of those students who chose accounting major responded with higher scores for this indicator. Of the 100 students who responded 'not at all' to the statement; 37 chose accounting while 63 did not choose accounting. There are 21 students who responded to have found the course to a small extent dominated by 
procedural rules chose accounting while 42 of them did not choose accounting and the 15 of students who responded that it dominated to some extent chose accounting while 53 of them did not choose accounting. For the 59 who responded that it was dominated to greater extent; 10 chose accounting while 49 did not choose accounting while of the 25 students who responded with extraordinary extent of domination; 6 chose accounting while 19 did not choose accounting. The general conclusion from the contingency table was drawn from a chi-square test which gave a chi-square statistic of 9.806 and a p-value of 0.044 which is less than 0.05 . This implies that the data shows a significant association between this indicator and choice of accounting major at $95 \%$ confidence and consequently rejecting the hypothesis developed in Section 2.5 on this indicator.

This finding is supported by a study which established that the procedural approach used in preparing financial statements that follows the GAAPs makes accounting boring and difficult for the students (Malthius \& Fowler, 2009). McDowall and Jackling,( 2010) ; Byrne and Willis, (2005) established that students' perceptions of accounting as following conventional rule than new ideas had a negative significant effect on choosing accounting as a career. Their finding supports the view that exposure to accounting at university does not enhance positive attitudes about accounting as a discipline; however, it reinforces rule-memorization, and lack of involvement with conceptual skills. This has been occasioned by the fact that students viewed accounting as a rule-based type of educational experience characterized by courses consisting of collections of rules to be memorized.

\subsection{Course Content and Choice of Accounting Major}

Bivariate analysis of the effect of course content was performed and the statistics summarized as shown in Table 4.4

Table 4.41: Model Summary of Course Content and Choice of Accounting Major

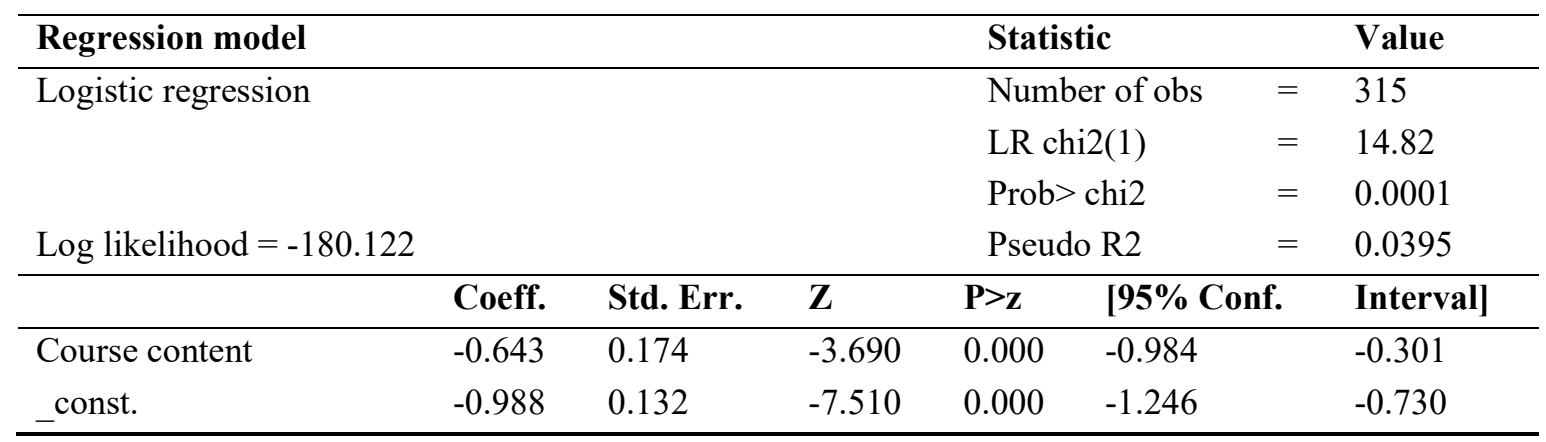

For the course content summary statistics, the pseudo R-square was found to be 0.0395 and the Chi-square p-value was 0.000 implying a significant model. Based on the value of pseudo R-square, we infer that course content explained $3.95 \%$ of the variation in the prediction of accounting major choice. The Likelihood ratio chi-square statistics was 14.82 with a p-value of $0.0001(<0.05)$, which implied that at 0.05 level of significant, the logistic regression model with course content is significant.

Also from Table 4.18, the statistics for the coefficients showed that the coefficient of course content was -0.643 yielding an equation given by

$$
\log _{e}\left(\frac{P(Y)}{1-P(Y)}\right)=-0.643-0.643 X
$$

Considering the $\mathrm{Z}$ statistic for the coefficient at 0.05 level of significance, the p-value was $0.000(<0.05)$ implied the coefficient was considered significant. From the coefficient of course content -0.643 , the odds ratio of the not choosing accounting corresponding to a unit increase in the levels of course content is given by

$$
e^{-0.643}=0.526
$$

Since the p-value of the $\mathrm{Z}$ statistic was less than 0.05 , we deduced that there is a significant proportional change in the odds of a student choosing accounting by 0.526 due to a unit increase in the levels of teaching methodology. 


\subsection{Course Content and Choice of Accounting Major}

Bivariate analysis of the effect of course content was performed and the statistics summarized as shown in Table 4.5

Table 4.52: Model Summary of Course Content and Choice of Accounting Major

\begin{tabular}{|c|c|c|c|c|c|c|c|}
\hline \multirow{2}{*}{\begin{tabular}{|l|} 
Regression model \\
Logistic regression
\end{tabular}} & & & \multicolumn{4}{|c|}{ Statistic } & \multirow{2}{*}{$\begin{array}{l}\text { Value } \\
315\end{array}$} \\
\hline & & & & Num & $r$ of obs & $=$ & \\
\hline & & & & LR & 2(1) & $=$ & 14.82 \\
\hline & & & & Prob & chi2 & $=$ & 0.0001 \\
\hline \multirow[t]{2}{*}{ Log likelihood $=-180.122$} & & & & Pseu & $\mathrm{R} 2$ & $=$ & 0.0395 \\
\hline & Coeff. & Std. Err. & $\mathbf{Z}$ & $\mathbf{P}>\mathbf{Z}$ & \multicolumn{2}{|c|}{ [95\% Conf. } & Interval] \\
\hline \multirow{2}{*}{$\begin{array}{l}\text { Course content } \\
\text { _const. }\end{array}$} & -0.643 & 0.174 & -3.690 & 0.000 & \multicolumn{2}{|l|}{-0.984} & -0.301 \\
\hline & -0.988 & 0.132 & -7.510 & 0.000 & \multicolumn{2}{|l|}{-1.246} & -0.730 \\
\hline
\end{tabular}

For the course content summary statistics, the pseudo R-square was found to be 0.0395 and the Chi-square p-value was 0.000 implying a significant model. Based on the value of pseudo R-square, we infer that course content explained $3.95 \%$ of the variation in the prediction of accounting major choice. The Likelihood ratio chi-square statistics was 14.82 with a p-value of $0.0001(<0.05)$, which implied that at 0.05 level of significant, the logistic regression model with course content is significant.

Also from Table 4.5, the statistics for the coefficients showed that the coefficient of course content was -0.643 yielding an equation given by

$\log _{e}\left(\frac{P(Y)}{1-P(Y)}\right)=-0.643-0.643 X$

Considering the $\mathrm{Z}$ statistic for the coefficient at 0.05 level of significance, the p-value was $0.000(<0.05)$ implied the coefficient was considered significant. From the coefficient of course content -0.643 , the odds ratio of the not choosing accounting corresponding to a unit increase in the levels of course content is given by

$e^{-0.643}=0.526$

Since the $\mathrm{p}$-value of the $\mathrm{Z}$ statistic was less than 0.05 , we deduced that there is a significant proportional change in the odds of a student choosing accounting by 0.526 due to a unit increase in the levels of course content

\subsection{Findings of the study:}

The main objective of the study was an assessment of the influence of Introductory Accounting Course on students' Choice of Accounting Major. The study established a positive significant relationship between Introductory Accounting Course and students' Choice of Accounting Major.

This finding is consistent with a study carried out in the United States of American Universities by Geiger and Oligby (2000) which established that students' perceptions towards the first course in accounting had a positive significant relationship with their intention to choose Accounting Major. A study by Hassan and Fauzi (2012), concurred, findings revealed that students performance in IAC had a positive significant relationship with students choice of Accounting Major in the Universities. A study by Seng and Tang (2016), On the other hand, found no relationship between Introductory Accounting Course and students' Choice of Accounting Major. The study established influencers of Accounting Major as earnings, job opportunities and market conditions.

\subsection{Limitations of the Study}

Conceptual limitation: The study used Introductory Accounting Course only. The study could have employed the use of other branches of accounting such as Cost Accounting and Managerial Accounting. However, Introductory Accounting Course is the foundation of all accounting. If students develop poor perceptions towards it, then same 
would be applicable to other branches of accounting. This will have effects on students Choice of Accounting Major.

Contextual limitation: The study was conducted among selected 12 Kenyan Universities. The study could have been conducted in all Kenyan Universities the offer Bachelors of Commerce program. However, since the 12 Universities were spread in all Kenyan regions, it was expected that they were a good representation of Kenya's Universities students' opinions.

Theoretical limitation: The study used the Theory of Wearing Two Hats and Theory of Planned Behaviour. The study could have used other theories such as Theory of Consumer Behaviour and social learning Theory, amongst others. However, the two theories informed the study variables.

Methodological limitation: The study employed the use of a descriptive cross sectional research design unlike longitudinal design. This was appropriate since data was collected within a short period from the 12 Universities. However, this didn't compromise the quality of the study.

\subsection{The Study's Contribution to Knowledge:}

Introductory Accounting Course in most cases has been given to unprepared Instructors in most Universities across the world. Experienced Instructors have looked down upon IAC. Instead this course has been allocated to fresh Instructors from colleges and Universities who lack teaching experience. In some cases it is given to Instructors who didn't take accounting specialization in Universities and thus lack the subject matter of accounting. In worse cases it is allocated to part time Instructors since it has a large populace. This is a problem since most part time Instructors and especially those in public Universities are not paid their salaries regularly. A hungry and angry Instructor is not expected to give quality input to students. The fact that IAC needs specialised attention in all Universities, would be the study's greatest contribution to the body of knowledge of accounting career

\subsection{Conclusion of the Study}

The study focused on Introductory Accounting Course as opposed to other studies that hitherto focused on other aspects like earnings, job market conditions and career opportunities as influencers of career choice among students in universities. In order to save the survival of accounting career, Introductory Accounting Course must undergo a complete overhaul and restructure. This should be in terms of assignment of qualified accounting Instructors who have vast experience using appropriate delivery methods and relevant teaching materials.

\section{References}

Ahinful, G., O., P. R., \& Danquah, J. B. (2012). Factors Influencing The Choice Of Accounting as a Major in Ghananian Universities. Journal Of Education and Practice, 3 (15), 101-105.

Byrne, M., \& Flood, B. (2008). Examining the Relationships Among Background Variables and Academic Performance of First Year Accounting Students at an Irish University. Journal of Accounting Education, 26 (4), 202-212.

Byrne, M., \& Willis, P. (2005). Irish Secondary Students' Perception of the Work of an Accountant and the Accounting Profession. Journal of Accounting Education, 14, 367-381.

Cooper, \& Schindler. (2011). Business Research Methods. McGraw-Hill Publishers.

Dalci, H., Turner, M., \& Baradarani, S. (2013). Journal of Accounting in Emerging Economics, 3 (2), 145-163.

Dibabe, T. S., Wubie, A., \& Wondmagegn, G. (2015). Factors that Affect Students Career Choice in Accounting: A Case of Bahir Dar University. Students Research Journal of Finance and Accounting, 6 (5), 146.

Geiger, M. A., \& Ogilby, S. M. (2000). The first course in accounting: student's perceptions and their effect on the decision in accounting. Paulines Publications Africa. 
Hunt, S., Falgiani, A., \& Intrieri, R. (2004). The Nature and Origins of Student's Perceptions of Accountants. Journal of Education for Business, 79, 142-148.

Jackling, B., \& Calero, C. (2006). Influences on Undergraduate Students' Intentions to Become Qualified Accountants. An International Journal of Accounting Education, 15 (4), 419-437.

Kenya Universities and Colleges Central Placement Services. (2016). Retrieved from http://www.kuccps.students.ac.ke Kenya Vision 2030. (2007). Government of Kenya.

Lanson, J. (2010). Retrieved August 10, 2010, from http://www.utusan.com.my/utusan /info.asp?y= (2009)\&dt=0713\&pub=Utu an Malaysia\&sec=Ekonomi\&London

Malthus, S., \& Fowler, C. (2008). Perceptions of Accounting: A quantitative New Zealand Study. Pacific Accounting Review, 21, 26- 47.

Marriott, P., \& Marriott, N. (2003). Are We Turning then On? A longitudinal Study of Undergraduate Accounting Students Attitudes Towards Accounting As A Profession. Accounting Education An International Journal,, 12 (2), 113- 133.

Mauldin, S., Crain, J., \& Mounce, P. (2000). The Accounting Principles Instructor's Influence on Students' Decision to Major in Accounting. Journal of Education for Business, 75 (3), 142-148.

McDowall, T., \& Jackling, B. (2010). Attitudes towards the accounting profession: An Australian Perspective. Asian Review of Accounting, 18 (1), 30 - 49.

Mohidin, R., Jaidi, J., Sang, T., \& Osman, Z. (2009). Effective Teaching Methods and Lecturer Characteristics. European Journal of Social Sciences, 8 (1), 21-29.

Mugenda, O., \& Mugenda, A. (2003). Research Methods:Qualitative and Quantitative methods. Nairobi, Kenya.

Omar, N. (2009). Factors influencing the Diploma in Accounting (DIA) student's decision to pursue professional accounting programmes performance in University-level Introductory Accounting Courses in Hong Kong. Journal of Education for Business, 74 (5), 301 - 306.

Principe, H. (2005). Factors Influencing Students' Academic Perfomance in the First Accounting Course: a Comparative Study Between Public and Private Universities in Puerto. New York, England: Haslow publishers.

Shattock, M. (2007). Higher Education Management and Policy. Journal of the Programme, 19 (2).

Wells, P. (2010). How makes Contacts with accountants influence Perceptions of accounting and Accountants. Auckland, New Zealand.

Zakaria, M., Wan Fauzi, W. A., \& Hassan, S. J. (2012). Accounting as a choice of academic program. journal of Business Administration Resaerch, 1 (1), 43 - 56. 